\title{
Depths and Thermal Habitat Used by Large versus Small Northern Pike in Three Minnesota Lakes
}

\author{
Rodney B. Pierce* \\ Minnesota Department of Natural Resources, Division of Fisheries and Wildlife, 1201 East Highway 2, \\ Grand Rapids, Minnesota 55744, USA
}

Andrew J. Carlson

Minnesota Department of Natural Resources, Division of Fisheries and Wildlife, 1601 Minnesota Drive, Brainerd, Minnesota 56401, USA

Bruce M. Carlson

University of Michigan, 1345 Waterford Drive, Golden Valley, Minnesota 55422, USA

\section{Dallas Hudson}

U.S. Geological Survey, Shingobee River Headwaters Station, 32390 Great Road, Akeley, Minnesota 56433, USA

\author{
David F. Staples \\ Minnesota Department of Natural Resources, Division of Fisheries and Wildlife, 5463-C West Broadway, \\ Forest Lake, Minnesota 55025, USA
}

\begin{abstract}
We monitored depths and temperatures used by large $(>71-\mathrm{cm})$ versus small Northern Pike Esox lucius in three north-central Minnesota lakes with either acoustic telemetry or archival tags. Individual Northern Pike demonstrated flexibility in depths used within a season and between years. The fish had some tolerance for low levels of dissolved oxygen $(<3 \mathrm{mg} / \mathrm{L})$, but depth selection was generally constrained by low dissolved oxygen in summer and winter. The fish more fully exploited all available depths during winter and thermal turnover periods. During July and August, large Northern Pike tended to follow the thermocline into cooler water as upper water layers warmed. Selection ratios indicated that large Northern Pike preferred water temperatures of $16-21^{\circ} \mathrm{C}$ during August when temperatures up to $28^{\circ} \mathrm{C}$ were available. In two lakes providing dense overhead cover from water lilies in shallow water, small Northern Pike used warmer, shallower water compared with large fish during summer. In a third lake providing no such cover, small fish were more often in deeper, cooler water. For small Northern Pike, temperature seemed to be a secondary habitat consideration behind the presence of shallow vegetated cover. This study provided detailed temperature selection information that will be useful when considering temperature as an ecological resource for different sizes of Northern Pike.
\end{abstract}

The Northern Pike Esox lucius is valued principally as a sport fish in Minnesota and elsewhere, and provides a tremendous source of recreational fishing opportunities (Pierce 2012). Recreational anglers and field biologists contend that large
Northern Pike use deeper, colder habitats than small adult Northern Pike (Jacobson 1992; Diana 1996). Thermoregulatory behavior by Northern Pike may serve to limit weight loss during the summer when surface waters exceed optimum temperatures for

*Corresponding author: rodney.pierce@state.mn.us

Received March 27, 2013; accepted June 27, 2013 
growth (Headrick 1985; Headrick and Carline 1993). In theory, differences in preferred habitats between large and small adult Northern Pike could be related to shifts in temperature-linked metabolic processes that optimize growth at lower temperatures as fish attain greater mass, but shifts in thermal habitat may be difficult to decouple from intraspecific interactions (e.g., competition and cannibalism) or the availability of different types and sizes of prey fish. The primary issue, at present, is that shifts in thermal habitats used as Northern Pike grow to larger sizes have not been documented.

Better information about water temperatures and depths used by different sizes of Northern Pike could contribute to management aimed at restoring larger sizes of Northern Pike, to the development of more accurate bioenergetics models assessing Northern Pike population-level and community-level dynamics, and to more accurate projections of how climate change will influence Northern Pike populations. Evaluations of the effectiveness and suitability of regulations designed to improve Northern Pike sizes depend on our understanding of habitat characteristics that help produce large Northern Pike (Paukert et al. 2001). Bioenergetics modeling has become increasingly important for tracking the consequences of fisheries management activities to individual species as well as to fish communities. Assumptions about habitats used by fish often underlie the thermal histories used in bioenergetics models (Hartman and Kitchell 2008). The magnitude of the effects of climate change on lakes depends on the lake's size, depth, and latitude, and the subsequent effects on fish such as Northern Pike are dependent on the temperatures they need to grow and persist (Stefan et al. 1995). In this study, we monitored Northern Pike use of water depths and thermal habitat throughout the year in three natural temperate lakes. Our objective was to accurately measure how large versus small Northern Pike selected depths and temperatures in relation to available habitats in the lakes.

\section{METHODS}

Three lakes located in north-central Minnesota were selected for this study (Table 1). Lakes were selected based on the presence of Northern Pike larger than $71 \mathrm{~cm}$ (the preferred size for recreational anglers; Anderson and Gutreuter 1983) and the availability of coolwater habitat during summer with enough dissolved oxygen to support Northern Pike. Therefore, in each of the lakes, Northern Pike could select from a wide range of available water temperatures that they could potentially use as habitat during summer. The primary difference in fish habitat among lakes was that Pillager and Shingobee lakes had more soft-bottom shoal areas and more extensive beds of shallow aquatic vegetation during summer than Little Wabana Lake.

Temperatures and depths used by small versus large Northern Pike were monitored using either acoustic telemetry or archival tags. Fish temperatures and depths (pressures) were obtained using acoustic transmitters (V13TP; Vemco, Halifax, Nova Scotia) and fixed-station data-logging hydrophones (Vemco VR2 and
TABLE 1. Latitude, longitude, total surface area, and maximum depth of study lakes along with the numbers and TLs of large versus small Northern Pike implanted with acoustic transmitters (Pillager and Little Wabana lakes) or archival tags (Shingobee Lake).

\begin{tabular}{|c|c|c|c|}
\hline \multirow{2}{*}{$\begin{array}{l}\text { Characteristics of } \\
\text { lakes and } \\
\text { study fish }\end{array}$} & \multicolumn{3}{|c|}{ Lake } \\
\hline & Pillager & Little Wabana & Shingobee_ \\
\hline \multicolumn{4}{|c|}{ Lakes } \\
\hline Latitude & $46^{\circ} 22^{\prime} \mathrm{N}$ & $47^{\circ} 24^{\prime} \mathrm{N}$ & $47^{\circ} 0^{\prime} \mathrm{N}$ \\
\hline Longitude & $94^{\circ} 29^{\prime} \mathrm{W}$ & $93^{\circ} 30^{\prime} \mathrm{W}$ & $94^{\circ} 41^{\prime} \mathrm{W}$ \\
\hline Surface area (ha) & 83.0 & 46.8 & 62.4 \\
\hline Maximum depth (m) & 11.9 & 17.4 & 12.2 \\
\hline \multicolumn{4}{|c|}{ Northern Pike } \\
\hline \multicolumn{4}{|l|}{ Number of fish } \\
\hline Large & 4 & 5 & 18 \\
\hline Small & 6 & 6 & 18 \\
\hline \multicolumn{4}{|l|}{ Lengths (mm) } \\
\hline Large & $730-1,020$ & 807-975 & $728-942$ \\
\hline Small & $487-607$ & $484-565$ & $471-520$ \\
\hline
\end{tabular}

VR2W) in Pillager and Little Wabana lakes, and archival tags (LAT1100; Lotek Wireless, Newmarket, Ontario) in Shingobee Lake. Transmitters in Pillager Lake had a temperature range of $0-20^{\circ} \mathrm{C}\left( \pm 0.5^{\circ} \mathrm{C}\right.$ accuracy), so measurements of warmer temperatures were not obtained. In Little Wabana Lake and Shingobee Lake, transmitters and tags had temperature ranges of $0-40^{\circ} \mathrm{C}( \pm 0.5 \%)$ and $0-35^{\circ} \mathrm{C}( \pm 0.2 \%)$. Study fish were trap-netted during ice-out in Pillager Lake (April 2009), Little Wabana Lake (April 2010), and Shingobee Lake (April 2011). Transmitters were surgically implanted through abdominal incisions (following winter 1983) in 10 fish from Pillager Lake and 11 fish from Little Wabana Lake, and archival tags were surgically implanted in 36 fish from Shingobee Lake (Table 1). Transmitters and tags were $0.07-1.80 \%$ of fish body weights predicted from length-weight regressions. Pressure readings for recovered archival tags were more closely calibrated to actual water depths by lowering the tags through a sequence of known depths. Similar tag calibrations were not performed for acoustic transmitters.

Thermal habitat available to Northern Pike in all three lakes was quantified by continuously monitoring water temperature throughout the water column at the deepest part of each lake. Hourly water temperature profiles were obtained using a string of data-logging thermistors (HOBO U22 Water Temp Pro version 2; Onset Computer, Bourne, Massachusetts) deployed at $0.5-$ to $1-\mathrm{m}$ depth intervals from the surface to the lake bottom in Little Wabana and Shingobee lakes. In Pillager Lake, which was open to public recreational use, thermistors were deployed from a depth of $3.2 \mathrm{~m}$ down to the lake bottom. Profiles of dissolved oxygen concentration with depth were obtained approximately weekly in each lake. Dissolved oxygen profiles were not 
obtained in early winter as ice was forming on the lakes, nor as ice was melting in the spring. Oxygen concentrations at each depth were measured using a luminescent dissolved oxygen probe and portable meter (LDO and HQ30d; Hach, Loveland, Colorado).

Volumes of water between $1{ }^{\circ} \mathrm{C}$ isotherms were integrated over time to calculate thermal habitat volumes for each month in each year. Isotherm depths were determined for each temperature profile (24 times/d) by interpolating depths for each $1^{\circ} \mathrm{C}$ temperature range. Volumes of water in each temperature range were further estimated from a hypsographic curve of lake volume in relation to lake depth (following Christie and Regier 1988). Finally, volumes from temperature profiles were summed over hourly time intervals to project the thermal habitat volume (expressed in cubic meter days) available to Northern Pike for each $1^{\circ} \mathrm{C}$ temperature range (Christie and Regier 1988).

Northern Pike temperature preferences were evaluated using selection ratios, which are ratios of fish use of various habitats compared with availability of those habitats. Rogers and White (2007) provided equations for calculating selection ratios for each habitat type $\left(w_{i}\right)$, expressed as

$$
\hat{w}_{i}=u_{i+} /\left(\pi_{i} u_{++}\right),
$$

where $u_{i+}$ is the number of observations in habitat type $i$ for all fish, $\pi_{i}$ is the proportion of available habitat in category $i$, and $u_{+}+$is the total number of habitat observations for all fish. Selection for a particular habitat is indicated by $\hat{w}_{i}>1$, whereas avoidance is indicated by $\hat{w}_{i}<1$. Each fish was considered a primary sampling unit so that SEs for selection ratios $\left(\mathrm{SE}\left[\hat{w}_{i}\right]\right)$ accounted for variation in resource selection among individual fish, expressed as

$$
\operatorname{SE}\left(\hat{w}_{i}\right)=\sqrt{\frac{n}{(n-1)\left(u_{++}\right)^{2}} \sum_{j=1}^{n}\left(\frac{u_{i j}}{\pi_{i}}-\hat{w}_{i}\left(u_{+j}\right)\right)^{2}},
$$

where $n$ is the number of fish, $u_{i j}$ is the number of observations in habitat type $i$ for fish $j$, and $u_{+j}$ is the total number of observations for fish $j$ (Rogers and White 2007).

In each lake, temperature selection ratios were calculated for August when a broad range of water temperatures was available to Northern Pike. Fish use of water temperatures was based on the number of observations of individual fish in $1^{\circ} \mathrm{C}$ temperature ranges. Available habitat was the thermal habitat volume calculated for each $1^{\circ} \mathrm{C}$ temperature range during August. Water layers with low levels of dissolved oxygen $(<3 \mathrm{mg} / \mathrm{L})$ were excluded from the thermal habitat volumes used in determining selection ratios because Casselman (1996) concluded that adult Northern Pike avoid oxygen concentrations $<3-4 \mathrm{mg} / \mathrm{L}$.

Patterns of Northern Pike habitat use were explored using linear mixed-effects models of hourly averages of telemetry observations for individual fish. The models were used to establish if fish size or season influenced temperatures and depths used by Northern Pike, and if daily changes in temperatures and depths occurred. Each fish was a primary sampling unit with a random effect incorporated into the model to account for repeated measurements of temperature and depth from each individual. A one-step autoregressive (AR1) correlation process was included for temporal correlation among observations in successive hours. The correlation was modeled as a function of the time interval (h) between successive observations to account for times when the fish was not near a hydrophone (Rogers and White 2007). Seasonal changes in fish behavior were determined by running the model for each month's observations in each lake and year. All models included the random effect structure described above, and specific fixed effects compared in each month were (1) an intercept-only model that provided an overall average of fish temperature or depth, (2) a model that included the hour of the day, (3) models that included the length or size category (large versus small) of the fish, (4) models that included both the hour of the day and the length (or size category) as additive fixed effects, and (5) a model that included an interaction between hour of the day and fish size. Models were fit using the lme function in the nlme package (Pinheiro et al. 2010) in the statistical program R (R Development Core Team 2012). Akaike's information criterion (AIC; Burnham and Anderson 2002) was used to choose among models fit for each month.

\section{RESULTS}

In Pillager Lake, six transmitters broadcasted data through the first summer and three broadcasted until spring 2010. In Little Wabana Lake, two transmitters broadcasted data until June 2011 and eight broadcasted until September 2011. In Shingobee Lake, archival tags were recovered during spring 2012 from 8 small and 12 large Northern Pike. Acoustic receivers captured between 29,922 and 92,150 observations of temperature or depth from each transmitter per year. Archival tags collected 17,692 temperature and depth observations per year.

\section{Depth Movements}

Depth observations from individual Northern Pike throughout the year illustrated (1) that the deepest movements occurred during spring and fall turnover periods when dissolved oxygen in deep water increased, (2) behaviors (use of depths) throughout the year varied among individual fish, (3) a seasonal pattern was often observed in summer depth movements, and (4) behaviors of some individual fish changed from one year to the next. Examples of deep movements during turnover periods were 484and 557-mm fish that went as deep as $15 \mathrm{~m}$ in Little Wabana Lake, and 735- and 866-mm fish that went over $11 \mathrm{~m}$ deep in Shingobee Lake (Figure 1). Individual behaviors were evident among small Northern Pike in Shingobee Lake during the summer. Most depths of small (471-502-mm) Northern Pike during summer were less than $2 \mathrm{~m}$, but one small (468-mm; Figure 2) fish used depths mostly greater than $4 \mathrm{~m}$, and a $498-\mathrm{mm}$ fish spent most of its time in depths between 2 and $4 \mathrm{~m}$. Fall and 


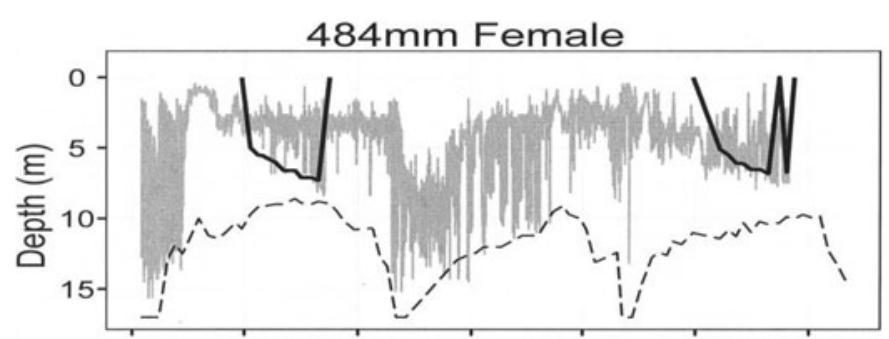

Apr-10 Jul-10 Oct-10 Jan-11 Apr-11 Jul-11 Oct-11
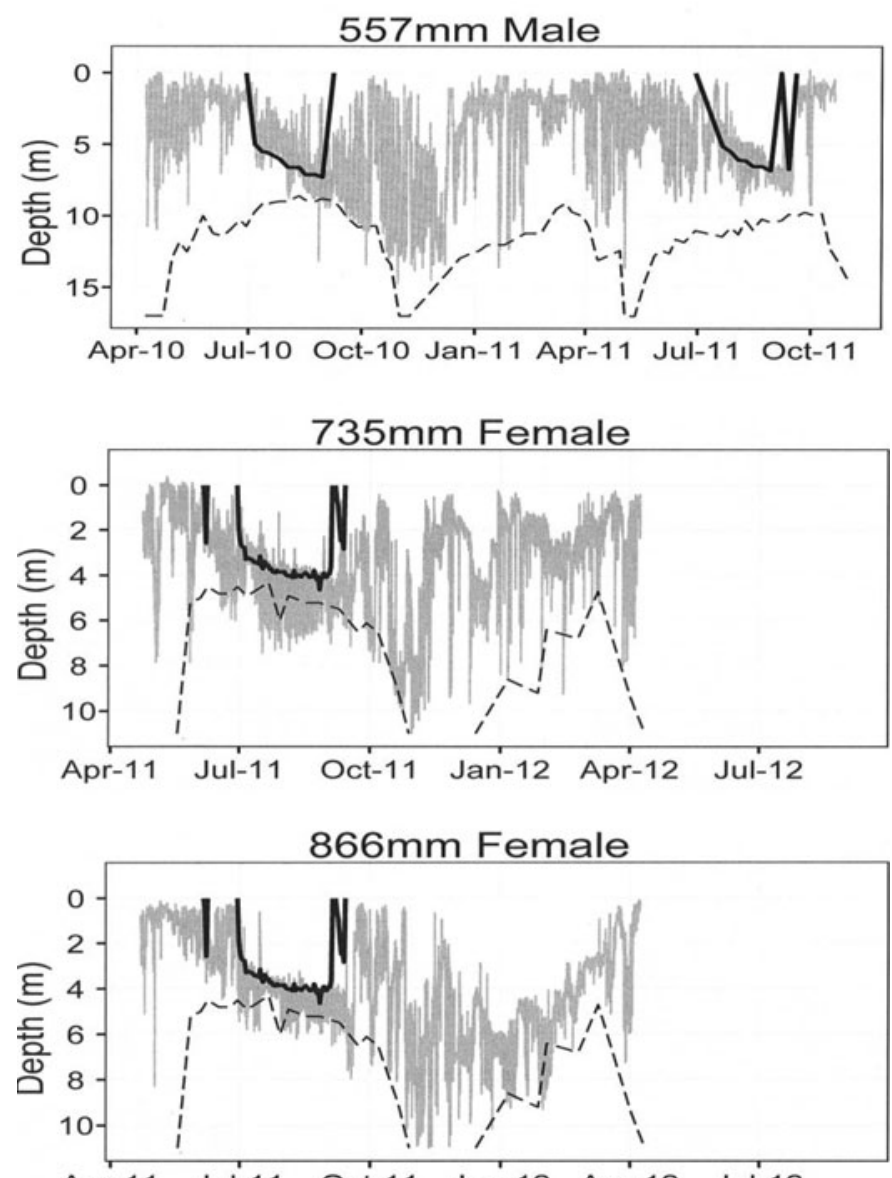

Apr-11 Jul-11 Oct-11 Jan-12 Apr-12 Jul-12

FIGURE 1. Sequential depth observations (gray lines) from small (484- and 557-mm) Northern Pike in Little Wabana Lake during April 2010 to September 2011, and from large (735- and 866-mm) Northern Pike in Shingobee Lake during April 2011 to April 2012. Solid black lines are depths where water temperature $=21^{\circ} \mathrm{C}$, and dashed lines indicate depths where dissolved oxygen $=3 \mathrm{mg} / \mathrm{L}$ as measured from temperature and oxygen profiles.

winter also provided examples of individual behaviors. In Little Wabana Lake, a 975-mm fish spent most of the fall and winter in water between 1 and $3 \mathrm{~m}$ deep (Figure 2). In contrast, an 807-mm fish spent most of the fall in moderate depth (2-6-m) water, but as the ice formed on the lake it moved deeper (mostly 9-14 m), spending much of the winter in deep water (Figure 2). Moreover, that same fish spent much of its time in water that had low concentrations of dissolved oxygen, including at least
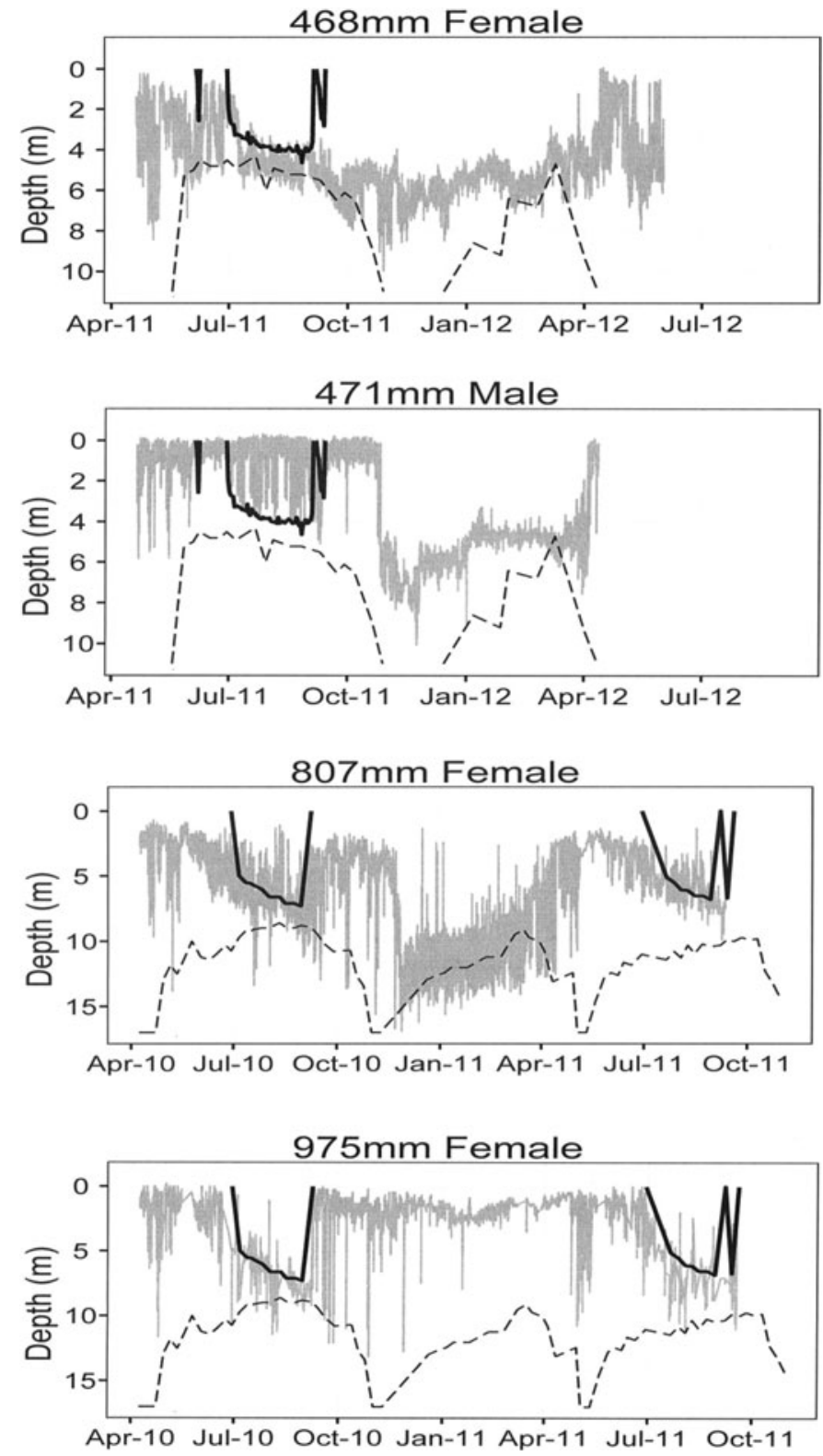

FIGURE 2. Sequential depth observations (gray lines) from small (468- and 471-mm) Northern Pike in Shingobee Lake during April 2011 to April 2012, and from large (807- and 975-mm) Northern Pike in Little Wabana Lake during April 2010 to September 2011. Solid black lines are depths where water temperature $=21^{\circ} \mathrm{C}$, and dashed lines indicate depths where dissolved oxygen $=3 \mathrm{mg} / \mathrm{L}$ as measured from temperature and oxygen profiles.

$47 \mathrm{~min}$ in water depths with less than $0.5 \mathrm{mg} / \mathrm{L}$ dissolved oxygen (less than $4 \%$ saturation) during one February excursion that went into water over $12 \mathrm{~m}$ deep.

Seasonal patterns in depth movements were most apparent during summer and were somewhat dependent on fish size. In all three lakes, large Northern Pike tended to occupy cooler water associated with the thermocline, with summer depths being 3-8 $\mathrm{m}$ depending on the lake (Figure 3). Large Northern Pike followed the thermocline into deeper water as warming 


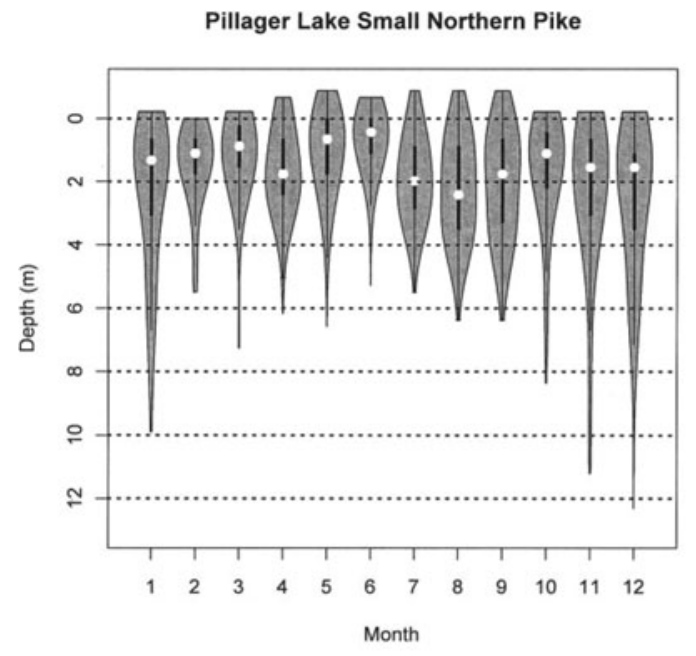

L. Wabana Lake Small Northern Pike

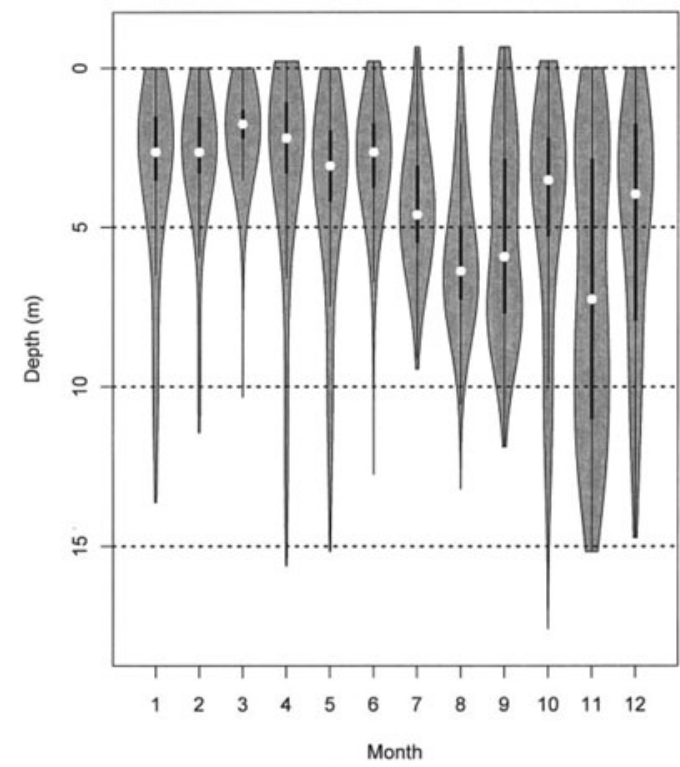

Shingobee Lake Small Northern Pike

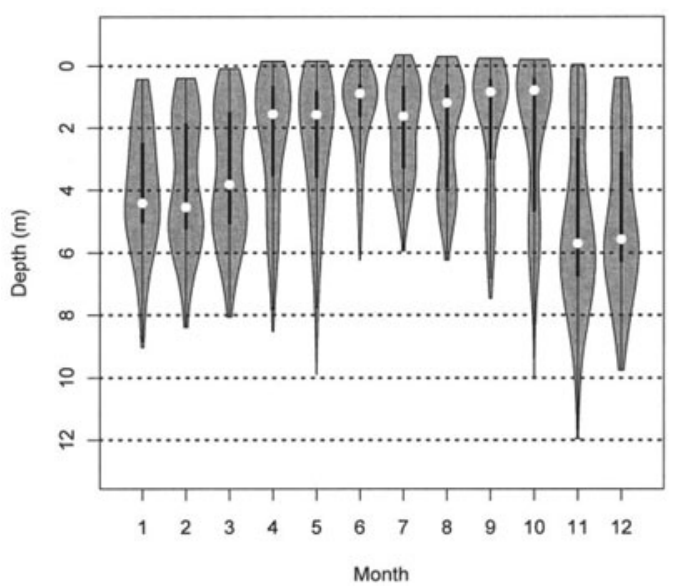

Pillager Lake Large Northern Pike

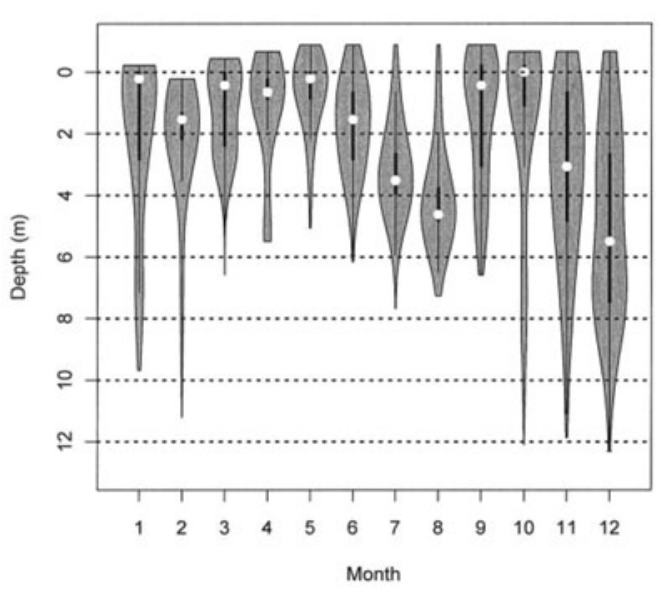

L. Wabana Lake Large Northern Pike

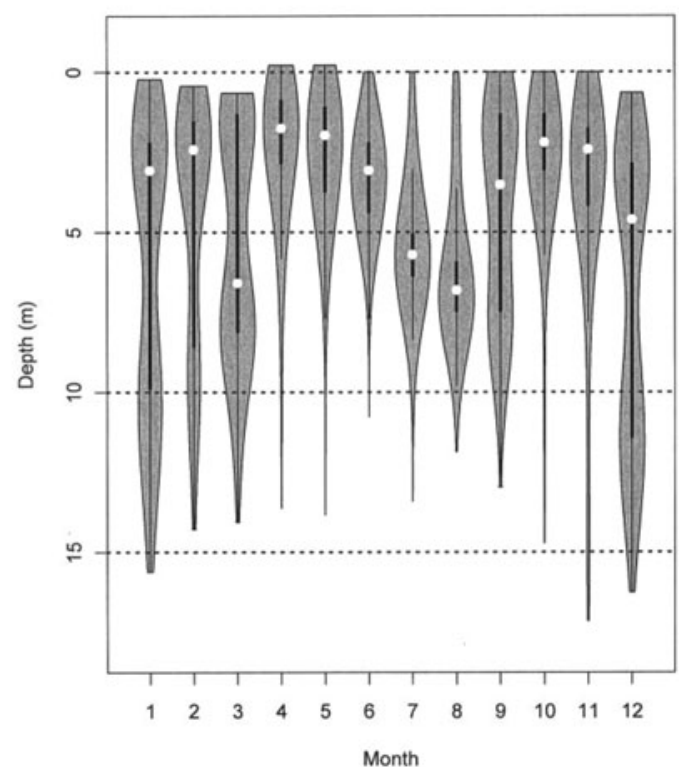

Shingobee Lake Large Northern Pike

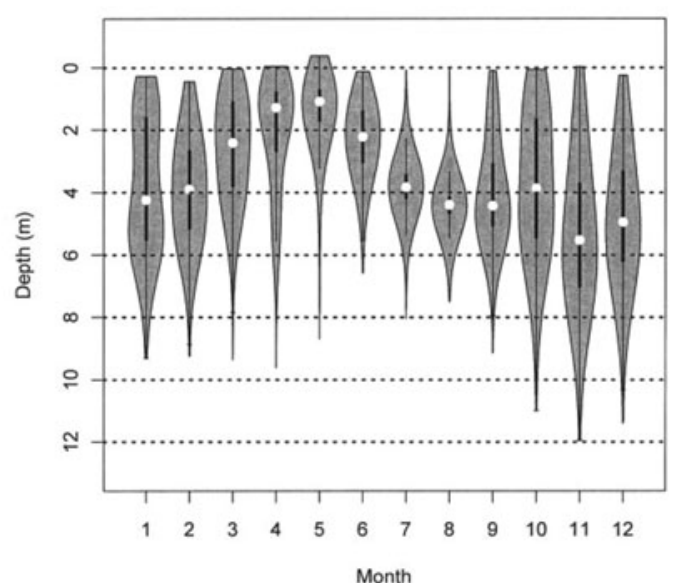

FIGURE 3. Violin plots (density traces) of monthly fish depth observations from small versus large Northern Pike in all three lakes. July and August are months 7 and 8 in the plots. White points represent median depths, and the thickest vertical line portions represent interquartile ranges. 

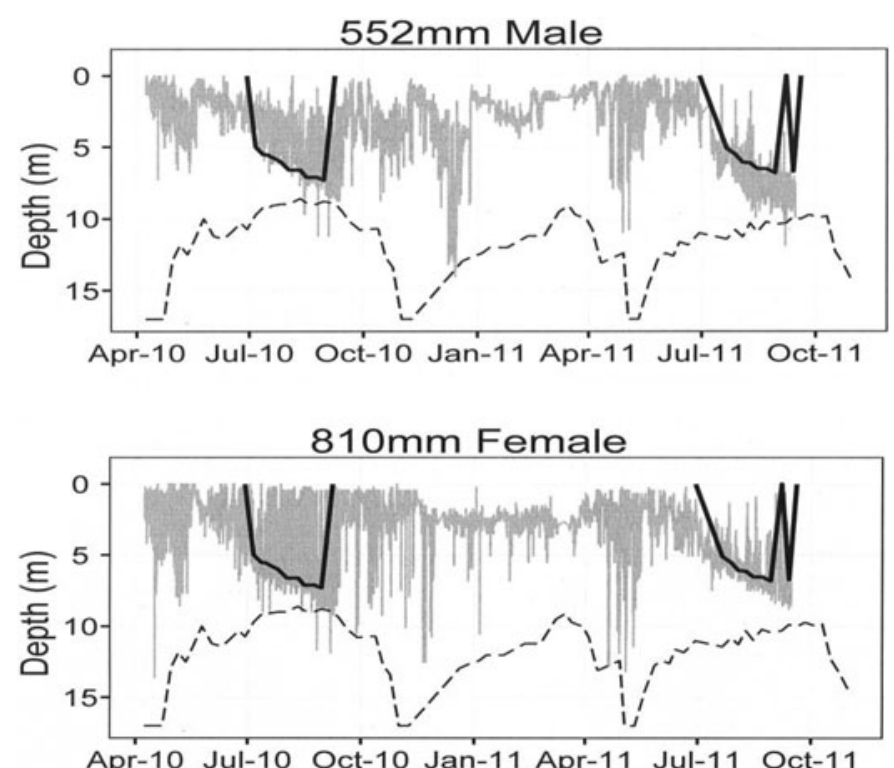

FIGURE 4. Sequential depth observations (gray lines) from 552- and 810mm Northern Pike in Little Wabana Lake during April 2010 to September 2011. Solid black lines are depths where water temperature $=21^{\circ} \mathrm{C}$, and dashed lines indicate depths where dissolved oxygen $=3 \mathrm{mg} / \mathrm{L}$ as measured from temperature and oxygen profiles.

temperatures in shallow water layers progressively drove the thermocline deeper during July and August. In contrast, small Northern Pike were found in either warm, shallow water $(<2 \mathrm{~m}$ deep) or the deeper water occupied by large Northern Pike (Figure 3). All large Northern Pike in Shingobee Lake maintained themselves in cooler water along the thermocline (Figure 3). Vertical movements in summer were generally constrained by low dissolved oxygen concentrations $(<3 \mathrm{mg} / \mathrm{L})$ in deeper water. Examples of fish switching behaviors from one year to the next were from Little Wabana Lake, where transmitters broadcasted through two summers. Two fish (552- and 810-mm fish; Figure 4) exhibited more extensive use of shallow, warmer water during summer 2010 compared with summer 2011, when both fish used depths that more closely followed the thermocline into deeper water during July and August.

\section{Temperature Selection in Oxygenated Water}

Temperatures at which Northern Pike maintained themselves throughout the year did not differ much between small and large Northern Pike except during July and August. In Little Wabana Lake, temperature observations each month were similar across fish sizes, especially during the water temperature transition periods of spring and fall (Figure 5). Differences in mean temperatures between small and large Northern Pike were only $0.02-0.89^{\circ} \mathrm{C}$ each month. The greatest difference in temperature observations between size categories was during July when there were a few more observations of warm temperatures among small fish $\left(\right.$ mean $\left.=21.00^{\circ} \mathrm{C} ; \mathrm{SE}=0.02^{\circ} \mathrm{C}\right)$ than large fish (mean $=20.11^{\circ} \mathrm{C}$; $\mathrm{SE}=0.02^{\circ} \mathrm{C}$; Figure 5). In Shingobee
Lake, temperatures of small and large Northern Pike were also similar among months $\left(\leq 0.4^{\circ} \mathrm{C}\right.$ difference in mean temperatures during September through June) except that much larger differences were apparent between the two size-groups during July and August (Figure 5). Mean (and SE) temperatures for small versus large fish were $22.79^{\circ} \mathrm{C}\left(0.03^{\circ} \mathrm{C}\right)$ versus $18.95^{\circ} \mathrm{C}$ $\left(0.02^{\circ} \mathrm{C}\right)$ in July and $22.16^{\circ} \mathrm{C}\left(0.03^{\circ} \mathrm{C}\right)$ versus $19.13^{\circ} \mathrm{C}\left(0.01^{\circ} \mathrm{C}\right)$ in August.

Selection ratios showed that large Northern Pike preferred to maintain cooler body temperatures of $16-21^{\circ} \mathrm{C}$ even though those water temperatures had somewhat limited availability to the fish during summer. Large Northern Pike in Little Wabana Lake selected for $17-21^{\circ} \mathrm{C}$ during August 2010 and $16-21^{\circ} \mathrm{C}$ during August 2011 when temperatures of $7.9-27.5^{\circ} \mathrm{C}$ were available (Table 2). In Shingobee Lake, large Northern Pike also selected for $16-21^{\circ} \mathrm{C}$ temperatures during August 2011 when temperatures of $14.6-28.1^{\circ} \mathrm{C}$ were available. In Pillager Lake, where the acoustic transmitters limited selection ratio calculations to temperatures less than $20^{\circ} \mathrm{C}$, temperature selection by large Northern Pike was apparent for $18-20^{\circ} \mathrm{C}$ during August 2009. Percentages of available thermal habitat less than $21^{\circ} \mathrm{C}$ were $23.3-34.6 \%$ of the August thermal habitat volumes in Little Wabana Lake and only $13.1 \%$ in Shingobee Lake. Water less than $20^{\circ} \mathrm{C}$ was only $11.2 \%$ of the thermal habitat volume available to Northern Pike in Pillager Lake during August. Selection ratios (Table 2) indicated that large Northern Pike in Little Wabana Lake avoided water greater than $22^{\circ} \mathrm{C}$ in both 2010 and 2011 even though 60.6-62.6\% of thermal habitat volumes were greater than $22^{\circ} \mathrm{C}$. In Shingobee Lake, large Northern Pike also avoided water greater than $22^{\circ} \mathrm{C}$, which was $75.2 \%$ of the available thermal habitat volume during August 2011. A few very high selection ratios at temperatures lower than $16^{\circ} \mathrm{C}$ were artifacts of a few fish observations in deep water at temperatures where the habitat was projected to be rare based on our calculations of habitat volume with a dissolved oxygen threshold of $3 \mathrm{mg} / \mathrm{L}$. Large Northern Pike in Shingobee Lake did not use shallow springs with cold groundwater flow even though numerous springs were found near the shoreline at depths less than $1 \mathrm{~m}$; simultaneous depths and temperatures from individuals indicated that no large fish took advantage of shallow pockets of cold water near shore during summer.

Small Northern Pike exhibited a more complex mix of thermal habitat preferences among the three lakes during August. Small Northern Pike tended to maintain their bodies at the same temperatures as large Northern Pike in Little Wabana Lake, but they often maintained warmer temperatures in the other two lakes. In Little Wabana Lake, small Northern Pike selected for temperatures of $18-19^{\circ} \mathrm{C}$ (Table 2). In Shingobee Lake, however, small Northern Pike selected for warmer water of $21-22^{\circ} \mathrm{C}$. Acoustic transmitters in Pillager Lake did not provide exact measurements for temperatures of $20^{\circ} \mathrm{C}$ and greater, but the transmitter data still enabled us to count observations $>20^{\circ} \mathrm{C}$. Those counts indicated that small Northern Pike in Pillager Lake were also using warm water: $94 \%$ of telemetered 
Wabana Lake Small Northern Pike

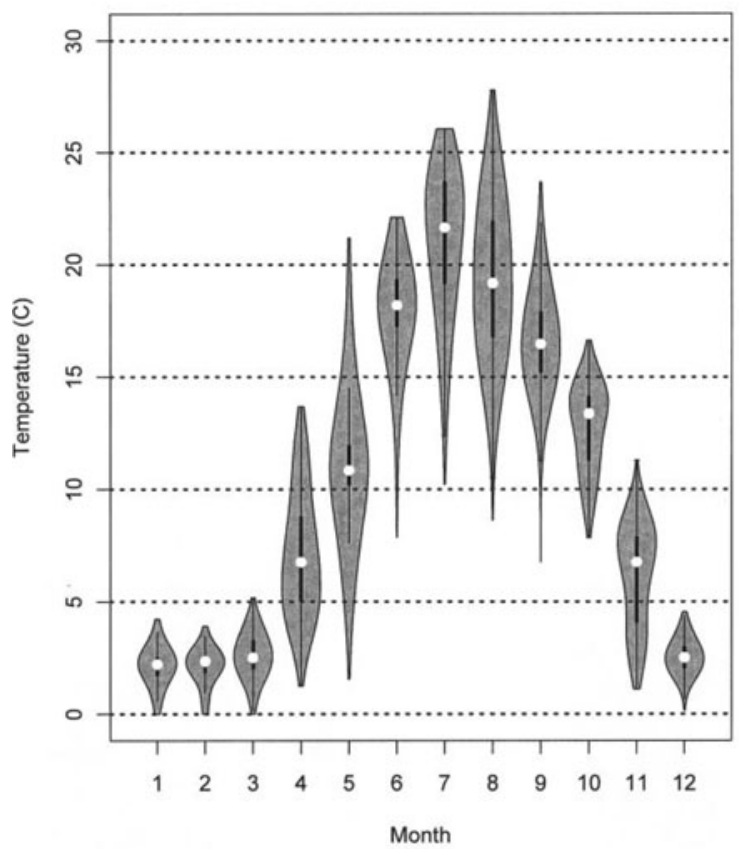

Shingobee Lake Small Northern Pike

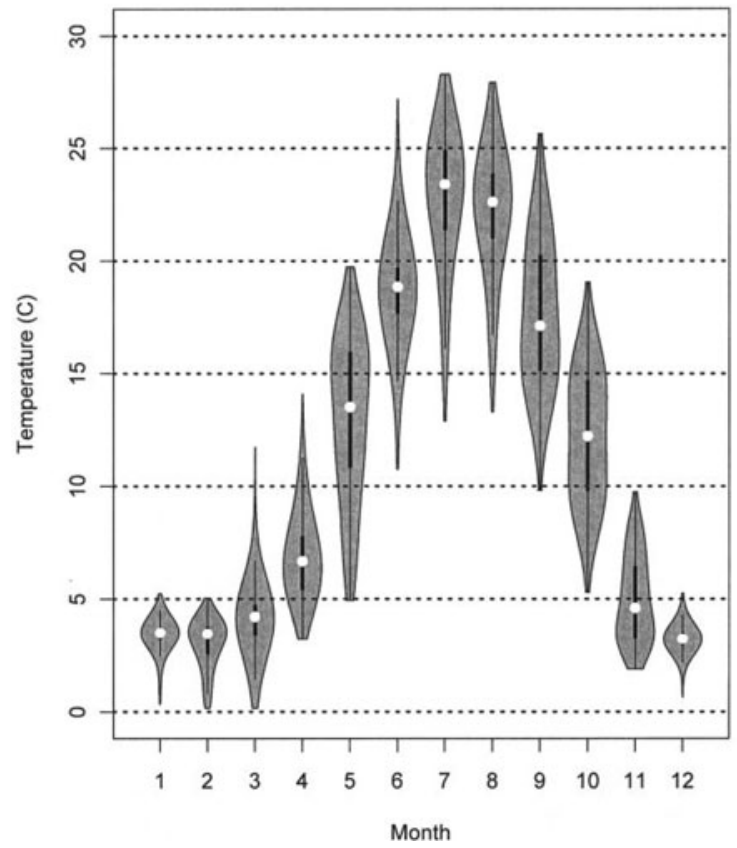

L. Wabana Large Northern Pike

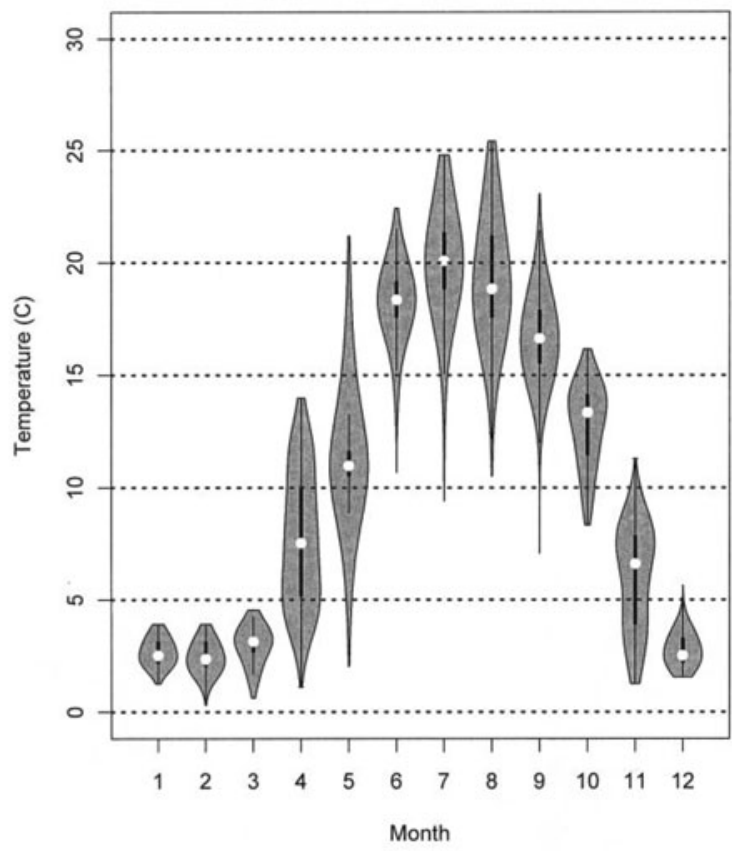

Shingobee Lake Large Northern Pike

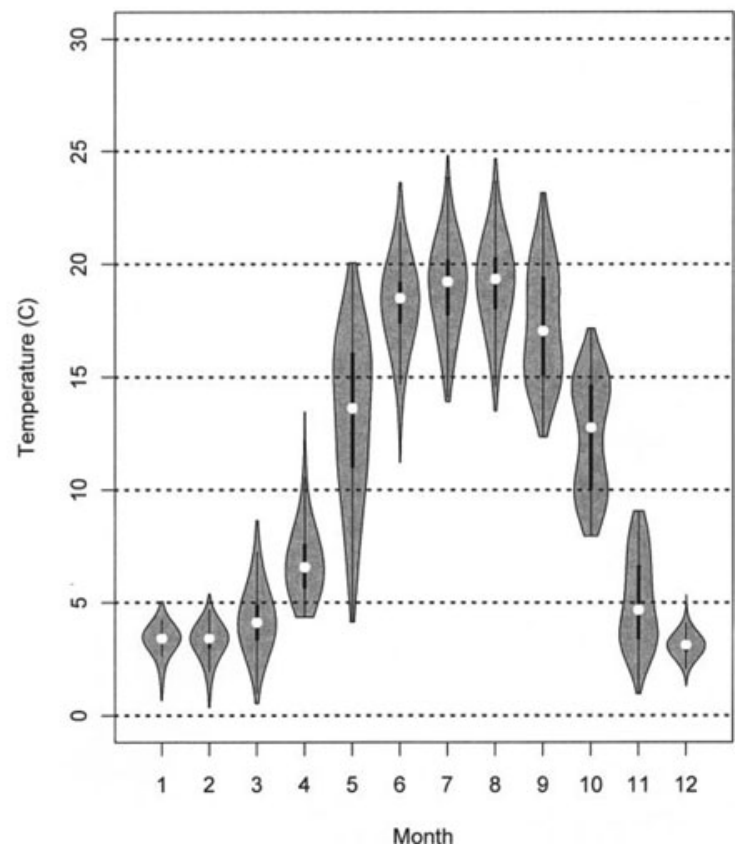

FIGURE 5. Violin plots (density traces) of monthly fish temperature observations from small versus large Northern Pike in Little Wabana and Shingobee lakes. July and August are months 7 and 8 in the plots. White points represent median temperatures, and the thickest vertical line portions represent the interquartile ranges.

temperature observations from small Northern Pike during August 2009 were for temperatures $>20^{\circ} \mathrm{C}$ compared with $37 \%$ from large Northern Pike. Similarly, $83 \%$ of temperature observations from small Northern Pike during August 2011 in Shin- gobee Lake were for temperatures $>20^{\circ} \mathrm{C}$. In contrast, observations $>20^{\circ} \mathrm{C}$ for small Northern Pike in Little Wabana Lake were only $35-47 \%$ of total observations during August in each year. 
TABLE 2. Selection ratios $\left(w_{i}\right)$ and SEs for selection ratios calculated for $1{ }^{\circ} \mathrm{C}$ water temperature ranges available to large and small Northern Pike during August in Pillager Lake (2009), Little Wabana Lake (2010 and 2011), and Shingobee Lake (2011). Selection ratios for temperatures $>20^{\circ} \mathrm{C}$ were not determined for Pillager Lake. Selection ratios with $95 \%$ CIs that exceeded $w_{i}=1.0$ are highlighted in gray. Zeros indicate temperatures that were available but not used by Northern Pike.

\begin{tabular}{|c|c|c|c|c|c|c|c|c|}
\hline \multirow[b]{3}{*}{ Temperature $\left({ }^{\circ} \mathrm{C}\right)$} & \multicolumn{8}{|c|}{$w_{i}(\mathrm{SE})$} \\
\hline & \multicolumn{2}{|c|}{ Pillager 2009} & \multicolumn{2}{|c|}{ Little Wabana 2010} & \multicolumn{2}{|c|}{ Little Wabana 2011} & \multicolumn{2}{|c|}{ Shingobee 2011} \\
\hline & Large & Small & Large & Small & Large & Small & Large & Small \\
\hline $7.0-7.9$ & & & & & 0 & 0 & & \\
\hline $8.0-8.9$ & & & & & 0 & 0 & & \\
\hline $9.0-9.9$ & & & & & 0 & 0 & & \\
\hline $10.0-10.9$ & & & & & $0.07(0.10)$ & $0.03(0.02)$ & & \\
\hline $11.0-11.9$ & & & 0 & 0 & $0.30(0.43)$ & $0.74(0.60)$ & & \\
\hline $12.0-12.9$ & & & $0.57(0.75)$ & $0.06(0.06)$ & $0.13(0.18)$ & $1.37(1.08)$ & & \\
\hline $13.0-13.9$ & & & 239 (316) & $119(71)$ & $0.13(0.18)$ & $1.76(1.16)$ & & \\
\hline $14.0-14.9$ & 0 & 0 & $0.14(0.15)$ & $0.83(0.45)$ & $0.03(0.05)$ & $2.15(1.09)$ & $185(141)$ & $66(59)$ \\
\hline $15.0-15.9$ & $1.65(1.31)$ & 0 & $1.65(1.56)$ & $2.49(1.73)$ & $2.08(0.81)$ & $3.91(1.44)$ & $6.39(2.47)$ & $4.25(3.92)$ \\
\hline $16.0-16.9$ & $2.33(1.30)$ & 0 & $3.13(1.44)$ & $3.47(1.33)$ & $7.25(1.63)$ & $5.04(2.26)$ & $3.94(0.65)$ & $1.72(1.63)$ \\
\hline $17.0-17.9$ & $5.88(3.12)$ & $0.01(0.01)$ & $5.35(2.31)$ & $4.18(1.36)$ & $8.96(0.31)$ & $4.91(1.53)$ & $3.91(0.38)$ & $1.10(0.90)$ \\
\hline $18.0-18.9$ & $6.74(1.62)$ & $0.16(0.07)$ & $7.62(0.88)$ & $4.29(1.13)$ & $11.97(0.95)$ & $5.09(1.16)$ & $5.16(0.61)$ & $0.81(0.38)$ \\
\hline 19.0-19.9 & $6.05(1.17)$ & $1.72(1.23)$ & $4.40(1.12)$ & $3.35(0.93)$ & $5.88(1.79)$ & $4.42(1.71)$ & $6.44(0.65)$ & $1.11(0.48)$ \\
\hline 20.0-20.9 & & & $3.07(0.95)$ & $2.93(1.25)$ & $4.63(0.87)$ & $3.98(1.85)$ & $4.35(0.45)$ & $1.72(0.48)$ \\
\hline $21.0-21.9$ & & & $0.69(0.22)$ & $0.66(0.22)$ & $2.18(0.46)$ & $3.83(2.30)$ & $1.05(0.22)$ & $1.85(0.16)$ \\
\hline $22.0-22.9$ & & & $0.39(0.08)$ & $0.43(0.20)$ & $0.23(0.01)$ & $0.49(0.25)$ & $0.12(0.06)$ & $0.75(0.11)$ \\
\hline $23.0-23.9$ & & & $0.39(0.11)$ & $0.30(0.10)$ & $0.04(0.01)$ & $0.21(0.13)$ & $0.05(0.03)$ & $0.81(0.16)$ \\
\hline $24.0-24.9$ & & & $0.32(0.08)$ & $0.65(0.31)$ & $0.04(0.02)$ & $0.18(0.14)$ & $0.02(0.02)$ & $1.13(0.23)$ \\
\hline $25.0-25.9$ & & & $0.09(0.04)$ & $0.32(0.13)$ & 0 & $0.01(<0.01)$ & 0 & $0.75(0.19)$ \\
\hline $26.0-26.9$ & & & 0 & 0 & 0 & 0 & 0 & $0.69(0.19)$ \\
\hline $27.0-27.9$ & & & 0 & $0.23(0.13)$ & 0 & 0 & 0 & $1.55(0.70)$ \\
\hline $28.0-28.9$ & & & & & & & 0 & 0 \\
\hline
\end{tabular}

\section{Habitat Modeling}

Models of Northern Pike habitat use (monthly models for each lake) indicated that the habitat used was often best described by an interaction between the time of day and the size of the fish (Table 3). The intercept-only model was the null model for comparisons with other models, and in only seven cases was the intercept-only model the best-supported model. Interceptonly models were useful during winter months that included

TABLE 3. Numbers of population-level models of depths and temperatures used by Northern Pike that were the best-supported models (i.e., had the lowest AIC values) for each of the possible lake and month combinations. Akaike's information criterion model selection determined the best-supported model from seven potential models for each month's observations of fish depths and temperatures. Models were developed for each of 9 months in Pillager Lake, 16 months in Little Wabana Lake, and 11 months in Shingobee Lake.

\begin{tabular}{lccccc}
\hline & \multicolumn{5}{c}{ Number of best-supported models for all lake-month combinations } \\
\cline { 2 - 6 } & $\begin{array}{c}\text { Interceptonly } \\
\text { only }\end{array}$ & Hour & Length & $\begin{array}{c}\text { Additive } \\
\text { hour }+ \text { length or } \\
\text { hour }+ \text { size category) }\end{array}$ & $\begin{array}{c}\text { Interaction } \\
\text { (hour } \times \text { length or } \\
\text { hour } \times \text { size category) }\end{array}$ \\
\hline $\begin{array}{l}\text { Depth } \\
\quad \text { Pillager Lake }\end{array}$ & 0 & 1 & 1 & 0 & 7 \\
$\quad$ Little Wabana Lake & 2 & 2 & 1 & 1 & 10 \\
$\quad$ Shingobee Lake & 1 & 0 & 0 & 4 & 6 \\
Temperature & 2 & 5 & 1 & 1 & 7 \\
$\quad$ Little Wabana Lake & 2 & 0 & 0 & 2 & 7 \\
$\quad$ Shingobee Lake & & & & & \\
\hline
\end{tabular}


December, February, and March for fish depth observations, and November, January, and February for fish temperature observations. Akaike's information criterion values for other models were less than the null model by 2-10 AIC units in seven cases, and by more than 20 units in 48 cases.

Niche dimensions for temperature and depth in each month were presented graphically along with modeling results for individual fish to illustrate how the fish distributed themselves seasonally in the available habitat (Figure 6). During the postspawning period in May, as temperatures were rapidly warming, large Northern Pike in Shingobee Lake stayed primarily in shallow water, but small Northern Pike were more evenly distributed down to 4-m water depth. During August, large Northern Pike were associated with the thermocline and dissolved oxygen concentrations $>3 \mathrm{mg} / \mathrm{L}$. Two of the small Northern Pike were also in deeper water, but most were in shallow water during August. When water temperatures were colder during November and February, both large and small Northern Pike were distributed throughout water deeper than $1.5 \mathrm{~m}$ that still had oxygen.

\section{DISCUSSION}

A salient feature of our results was the individualistic nature of Northern Pike behavior. Not only did individual fish demonstrate flexibility in their use of habitats within a season, but the Little Wabana Lake data also revealed individuals changing the way they used lake habitats between one year and the next. A radiotelemetry study in two Danish lakes with different environments came to the same conclusion that Northern Pike behavior is highly variable and that variation not only occurs between but also within locations and populations (Jepsen et al. 2001). Moreover, the Danish study implied that individual behaviors may explain many of the discrepancies observed between results of various studies of Northern Pike ecology. In a small German lake, Kobler et al. (2009) concluded that behavioral diversification among Northern Pike reduced intraspecific competition in preferred habitats.

Although individual behaviors were important, some patterns of habitat use were apparent among our three natural lakes. Vertical movement by Northern Pike of all sizes was generally constrained by low levels of dissolved oxygen, with most depth readings in water with $>3 \mathrm{mg} / \mathrm{L}$ dissolved oxygen. Large Northern Pike avoided shallow springs with cold groundwater flow presumably due to low levels of dissolved oxygen in the groundwater. When the entire water column became more fully oxygenated during spring and fall circulation and thermal overturn periods, Northern Pike more fully exploited all of the depths that became available to them.

Northern Pike also demonstrated that they could tolerate lower concentrations of dissolved oxygen during winter than many other fish species. Some of our winter fish depth measurements corresponded to portions of the water column with $<0.5 \mathrm{mg} / \mathrm{L}$ of dissolved oxygen, confirming earlier observations that Northern Pike are relatively tolerant of winterkill con- ditions. Moyle and Clothier (1959) noted how Northern Pike were able to persist over winter in a shallow western Minnesota lake with winter oxygen concentrations that ranged as low as $0.9-2.7 \mathrm{mg} / \mathrm{L}$.

During summer, behavior of large Northern Pike was generally consistent among the study lakes with large Northern Pike following the thermocline into deeper, cooler water as upper water layers warmed through the summer. The lower portion of their selected temperature range $\left(16-18^{\circ} \mathrm{C}\right)$ was lower than previously determined preferred temperatures and optimum temperatures for growth of Northern Pike. Preferred temperatures (temperatures selected under experimental laboratory conditions) have not been determined for large sizes of Northern Pike but were found to be $23-24^{\circ} \mathrm{C}$ for juveniles and subadults (McCauley and Casselman 1981). Casselman (1978) measured an optimum temperature of $19^{\circ} \mathrm{C}$ for growth in weight of laboratory-held yearlings and adults, and an optimum temperature of $21^{\circ} \mathrm{C}$ for growth in length. The adult fish ranged up to age 3 and were only 281-466-mm TL. In those studies, maximum swimming activity under laboratory conditions occurred at $19-20^{\circ} \mathrm{C}$. Comparing optimum temperatures for growth (in length) of 2- and 3-year-old fish between laboratory and field studies, Casselman (1978) found a very similar optimum temperature of $19.8^{\circ} \mathrm{C}$ in a lake.

In contrast to large Northern Pike, habitats used by small Northern Pike differed among lakes during the summer. Small Northern Pike in Pillager and Shingobee lakes tended to use warmer, shallower water than the large Northern Pike, but in Little Wabana Lake, the small fish were more often in deeper and cooler water. Temperatures selected by small Northern Pike in Shingobee Lake during August $\left(21-22^{\circ} \mathrm{C}\right)$ did not overlap with temperatures selected by large Northern Pike or even with temperatures selected by the small Northern Pike in Little Wabana Lake. The limited fish temperature information from Pillager Lake points to similar habitat preferences for small fish in both Shingobee and Pillager lakes. The principal habitat difference among these lakes was the amount of shallow-water aquatic vegetation providing overhead cover for fish. Nearshore areas in Shingobee Lake were nearly completely ringed with white water lily Nymphaea odorata and yellow pond lily Nuphar variegatum pads providing dense overhead cover from shore out to 2-m-deep water. Pillager Lake had one large shallow bay with dense overhead cover from lily pads. Manual tracking of acoustic transmitters found the small Northern Pike residing in that shallow vegetation. In contrast, Little Wabana Lake had more sparse aquatic vegetation, no lilies or overhead cover for small Northern Pike. Overhead cover and vegetated structure in shallow water in Shingobee and Pillager lakes likely provided some shading from direct heating by sunlight, habitat for forage fish and other potential food items as well as hiding cover from larger Northern Pike and avian predators. For small Northern Pike, temperature seemed to be a secondary habitat consideration behind the presence of shallow vegetated cover, and when cover was not available, small Northern Pike tended to follow 

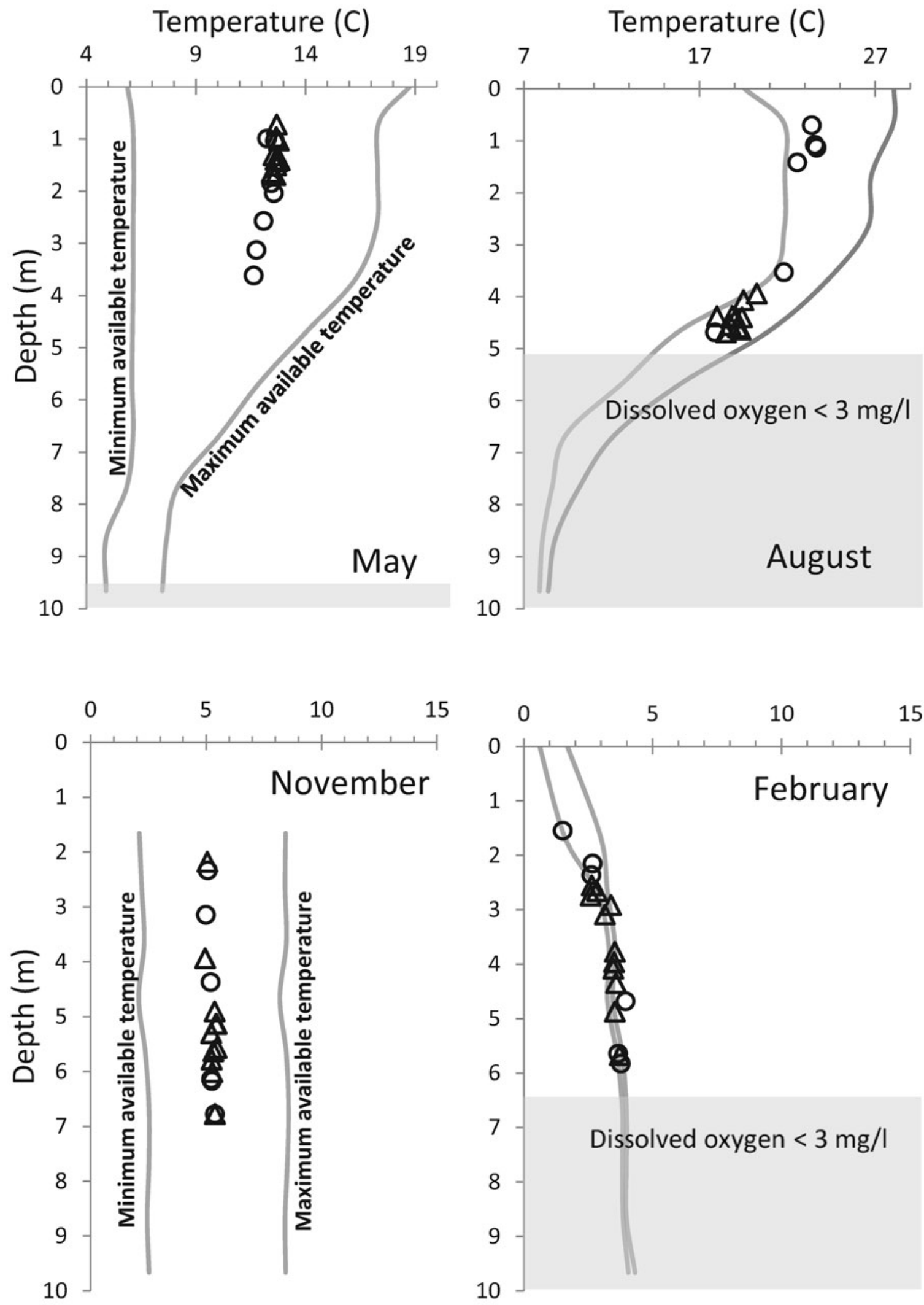

FIGURE 6. Dimensions of temperature and depth habitats used by Northern Pike in Shingobee Lake during 4 months. Gray lines represent the minimum and maximum temperatures available at each depth during the month. Shaded areas are depths with low $(<3-\mathrm{mg} / \mathrm{L})$ dissolved oxygen concentrations. Circles (small Northern Pike) and triangles (large Northern Pike) are predicted temperatures and depths of individual fish from monthly models. 
the large Northern Pike into deeper and cooler water during the summer.

Use of vegetation by small Northern Pike is consistent with previous studies. For example, small Northern Pike were usually caught in the densest plant beds and large fish were in more sparse vegetation in two shallow Ontario lakes (Casselman and Lewis 1996). Similarly, an inverse relationship was found between Northern Pike sizes and the density of aquatic plants in a small (27-ha) Swedish lake, suggesting that the small Northern Pike stayed in dense vegetation to avoid interactions with larger Northern Pike (Eklöv 1997).

We did not attribute differences in habitats used to differences in prey fish availability because the lakes had very similar prey fish species and large numbers of warmwater centrarchids (Minnesota Department of Natural Resources, unpublished lake survey data). All three lakes had coldwater Cisco Coregonus artedi, an important prey fish for Northern Pike (Jacobson 1992), although it was present in only trace numbers in Little Wabana Lake. Shingobee Lake was the only lake lacking introduced Walleye Sander vitreus, a coolwater species.

Applying relatively new technological advances in automated acoustic telemetry and archival tags, we were able to determine temperatures and depths used by Northern Pike with a degree of resolution that has not previously been available for natural lakes. This study provided detailed temperature selection information that could be useful for bioenergetics modeling (Hartman and Kitchell 2008), for projecting the influences that climate change may have on different sizes of Northern Pike, and for explaining differences among lakes in their capacity to produce large Northern Pike.

\section{ACKNOWLEDGMENTS}

We thank Beth Holbrook, Melissa Drake, Don Pereira, two anonymous reviewers, and the journal's editorial staff for improving the manuscript. This study was funded in part by the Federal Aid in Sport Fish Restoration (Dingell-Johnson) Program (D-J Project F26-R, Study 685, Minnesota), and more detailed data from this study will be published in a Minnesota Department of Natural Resources Fisheries Investigational Report. Reference to trade names does not imply endorsement by the U.S. Government.

\section{REFERENCES}

Anderson, R. O., and S. J. Gutreuter. 1983. Length, weight, and associated structural indices. Pages 283-300 in L. A. Nielsen and D. L. Johnson, editors. Fisheries techniques. American Fisheries Society, Bethesda, Maryland.

Burnham, K. P., and D. R. Anderson. 2002. Model selection and multimodel inference: a practical information-theoretic approach, 2nd edition. Springer, New York.

Casselman, J. M. 1978. Effects of environmental factors on growth, survival, activity, and exploitation of Northern Pike. Pages 114-128 in R. L. Kendall, editor. Selected coolwater fishes of North America. American Fisheries Society, Special Publication 11, Bethesda, Maryland.
Casselman, J. M. 1996. Age, growth and environmental requirements of pike. Pages 69-101 in J. F. Craig, editor. Pike: biology and exploitation. Chapman and Hall, London.

Casselman, J. M., and C. A. Lewis. 1996. Habitat requirements of Northern Pike (Esox lucius). Canadian Journal of Fisheries and Aquatic Sciences 53(Supplement 1):161-174.

Christie, G. C., and H. A. Regier. 1988. Measures of optimal thermal habitat and their relationship to yields for four commercial fish species. Canadian Journal of Fisheries and Aquatic Sciences 45:301-314.

Diana, J. S. 1996. Energetics. Pages 103-124 in J. F. Craig, editor. Pike: biology and exploitation. Chapman and Hall, London.

Eklöv, P. 1997. Effects of habitat complexity and prey abundance on the spatial and temporal distributions of perch (Perca fluviatilis) and pike (Esox lucius). Canadian Journal of Fisheries and Aquatic Sciences 54:1520-1531.

Hartman, K. J., and J. F. Kitchell. 2008. Bioenergetics modeling: progress since the 1992 symposium. Transactions of the American Fisheries Society 137:216-223.

Headrick, M. R. 1985. Bioenergetic constraints on habitat use by Northern Pike (Esox lucius) in Ohio reservoirs. Doctoral dissertation. Ohio State University, Columbus.

Headrick, M. R., and R. F. Carline. 1993. Restricted summer habitat and growth of Northern Pike in two southern Ohio impoundments. Transactions of the American Fisheries Society 122:228-236.

Jacobson, P. C. 1992. Analysis of factors affecting growth of Northern Pike in Minnesota. Minnesota Department of Natural Resources, Section of Fisheries, Investigational Report 424, St. Paul.

Jepsen, N., S. Beck, C. Skov, and A. Koed. 2001. Behavior of pike (Esox lucius L.) $>50 \mathrm{~cm}$ in a turbid reservoir and in a clearwater lake. Ecology of Freshwater Fish 10:26-34.

Kobler, A., T. Klefoth, T. Mehner, and R. Arlinghaus. 2009. Coexistence of behavioural types in an aquatic top predator: a response to resource limitation? Oecologia 161:837-847.

McCauley, R. W., and J. M. Casselman. 1981. The final preferendum as an index of the temperature for optimum growth in fish. Pages 81-93 in K. Tiews, editor. Proceedings of a world symposium on aquaculture in heated effluents and recirculation systems, volume 2. Heenemann VerlagsgesellSchaft, Berlin.

Moyle, J. B., and W. D. Clothier. 1959. Effects of management and winter oxygen levels on the fish population of a prairie lake. Transactions of the American Fisheries Society 88:178-185.

Paukert, C. P., J. A. Klammer, R. B. Pierce, and T. D. Simonson. 2001. An overview of Northern Pike regulations in North America. Fisheries 26(6):613.

Pierce, R. B. 2012. Northern Pike: ecology, conservation, and management history. University of Minnesota Press, Minneapolis.

Pinheiro, J., D. Bates, S. DebRoy, D. Sarkar, and the R Development Core Team. 2010. nlme: linear and nonlinear mixed effects models, $\mathrm{R}$ package version 3.1-97. R Foundation for Statistical Computing, Vienna.

R Development Core Team. 2012. R: a language and environment for statistical computing. R Foundation for Statistical Computing, Vienna. Available: www.R-project.org. (September 2012).

Rogers, K. B., and G. C. White. 2007. Analysis of movement and habitat use from telemetry data. Pages 625-676 in C. S. Guy and M. L. Brown, editors. Analysis and interpretation of freshwater fisheries data. American Fisheries Society, Bethesda, Maryland.

Stefan, H. G., M. Hondzo, J. G. Eaton, and J. H. McCormick. 1995. Predicted effects of global climate change on fishes in Minnesota lakes. Pages 57-72 in R. J. Beamish, editor. Climate change and northern fish populations. Canadian Special Publication of Fisheries and Aquatic Sciences 121.

Winter, J. D. 1983. Underwater biotelemetry. Pages 371-395 in L. A. Nielsen and D. L. Johnson, editors. Fisheries techniques. American Fisheries Society, Bethesda, Maryland. 